\title{
BACTERIA AND YEASTS IN PRIMARY SCHOOL: A LABORATORY APPROACH TO THE STUDY OF MICROBIOLOGY AND BIOTECHNOLOGIES
}

\author{
Anna Lago $^{1 \mathrm{e}}$, Silvia Masiero ${ }^{2 \mathrm{e}}$, Marta Bellio ${ }^{3}$, Elisabetta Piva ${ }^{4}$, Sophia Schumann ${ }^{5}$, \\ Paola Irato ${ }^{6}$, Gianfranco Santovito ${ }^{6 *}$ \\ ${ }^{1}$ Dr, University of Padova, ITALY, lagoanna92@gmail.com \\ ${ }^{2}$ Dr., University of Padova, ITALY, silvia.masiero.6@studenti.unipd.it \\ ${ }^{3} \mathrm{Dr}$, University of Padova, ITALY, marta.bellio@ unipd.it \\ ${ }^{4} \mathrm{Dr}$, University of Padova, ITALY, elisabetta.piva.2@studenti.unipd.it \\ ${ }^{5} \mathrm{Dr}$, University of Padova, ITALY, sophia.shumann@studenti.unipd.it \\ ${ }^{6}$ Dr, University of Padova, ITALY, paola.irato@unipd.it \\ ${ }^{7}$ Prof, University of Padova, ITALY, gianfranco.santovito@studenti.unipd.it \\ ${ }^{*}$ Corresponding author \\ ${ }^{\mathrm{e} B o t h}$ authors contributed equally to this work
}

\begin{abstract}
The present work consists in an experimental research based on the teaching and learning of Biology in primary school. The aims of this research are two. The first is to support the current scientific evidence that underlines the effectiveness of laboratory didactics. The second is to prove that this method makes it possible to deal with several topics which are not currently mentioned in the Italian Guidelines. Nowadays, scientific evidence demonstrates that laboratory didactics has a stronger impact on lifelong learning than traditional didactic approaches, based on frontal lessons only. The epistemological and methodological structure is clear: Science, especially Biology, should not just be taught for their products (concepts, theories, innovations,) but also, and especially, for their processes. Therefore, laboratory activities, conducted through experimental methods, represent one of the best resources in order to develop problemsolving skills, which underline a scientific mind. In the laboratory, every question or curiosity leads to new discoveries. In this way students gradually come to formalize their scientific knowledge. The teacher's role is to suspend the immediate explanation. He should be able to support spontaneous questions by students and the possibility to make hypothesis based on their naive theories. Starting from children's curiosity, it also makes possible to consider aspects that really intrigue them, but which are usually omitted by school programs, as they are considered too "far" from pupils' actual cognitive ability. Children, unlike adults, do not tend to take anything for granted and are fascinated and intrigued by everything around them, regardless of their hypothetical complexity. For this reason, teaching Biology in this way means to support students' intrinsic motivation, giving them not only scientific notions, but also concrete answers with practical implications in their daily lives. In this research, we followed children's interest for the microscopic world, and we treated microbiology and its biotechnological applications in food industry. We started from bread and yogurt productions, which are very close to students' reality, in order to introduce the topic of biotechnological applications using yeast (Saccharomyces cerevisiae) and bacteria (Streptococcus thermophilus and Lactobacillus bulgaricus). It was surprising for children to "discover" that the dough of a bakery product and a dairy product are actually a living material. As a matter of fact, the billion cells of living microorganisms, the yeasts and the bacteria, are in fact the protagonists of fermentation processes. In conclusion, considering the outcomes of our research, it is clear that the educational implications of
\end{abstract}


laboratory didactics are very significant and therefore not negligible. Moreover, this work would be an exhortation for teachers to use this method and to become a potential changing agent.

Keywords: bacteria, life sciences, microbiology, primary school, scientific method, yeasts.

\section{INTRODUCTION}

In primary school and in the first cycle of education, Biology falls within the competence of general Sciences and, of course, it is unthinkable to deepen all its arguments, given the few available hours dedicated to this subject. However, it is possible to provide the students of a comprehensive view of this discipline. In pursuing this, it should get some significant milestones of Sciences in general, such as educating students to the scientific method. teaching the precision, working with hand and eye together in a coordinated manner mind, developing interdisciplinarity, breaking down the boundaries between one discipline and another (Alfieri et al., 1995; Longo, 1998).

In teaching Science, an appropriate framework for this purpose is the laboratory. The laboratory is a place where everything makes sense and it is an operational context for building not only Life Sciences knowledge, but also for developing the knowledge of other disciplines.

In the World and European scene, many studies analysed what are the most significant approaches to improve the learning of Sciences (Gaiotto et al., 2013, 2020; Tonon et al., 2013, 2020; Pavan and Santovito, 2014; Zandonella Necca et al., 2014, 2021; Toninato and Santovito, 2015; Trevisan and Santovito, 2015; Gaiotto and Santovito, 2016; Rossi and Santovito, 2016; Capparotto et al., 2017; Favaron et al., 2017; Lago et al., 2017; Meneghetti et al., 2017; Barbacovi et al., 2018; Fassinato et al., 2018; Forlin et al., 2018; Grando et al., 2018a, 2018b; Tura et al., 2018; Chiesa et al., 2019; Gallina et al., 2019; Lui et al., 2019; Palmieri et al., 2019; Bortolami et a., 2020; Corbolino et al., 2020; Fabris et al., 2020; Zanata and Santovito, 2020; Barana et al., 2021; Bassi et al., 2021; Bertoncello et al., 2021; Frigerio et al., 2021; Furlan et al., 2021; Furlanetto et al., 2021; Pavan et al., 2021). Nevertheless, it was found that these practices are not used in the Italian school (Calvani, 2011).

This work consists of an experimental research based on the teaching and learning of Biology in a primary school (ten-year-old children). The main goal is to prove that this method makes it possible to deal with several topics which are not currently mentioned in the Italian Guidelines of 2012 for primary school (Castoldi, 2011), but for secondary school.

Our didactic project revolved around a topic that is not frequently considered by primary school programs: microbiology and their biotechnology application. The obtained results proved that student interest in microscopic reality have a positive influence on their motivation to learn.

\section{MATERIALS AND METHODS}

\subsection{The background and the Description of the Projects}

The two educational experiences were conducted in two different school backgrounds, both located in the North-East of Italy, in the Veneto region.

The first project was carried out with sixteen 10-year-old students at the "Montegrappa" primary school, in Galliera Veneta, Italy. It was developed around the approach of the biotechnology study of the fermentation of the yeast Saccharomyces cerevisiae.

Using three laboratory-experimental activities, pupils understood the biological yeast fermentation process. Moreover, they understood that:

- To make the bread dough "swell", it is necessary to use water, flour and yeast.

- The yeast, a live organism, is the element that determines the "swelling" of the dough.

- The swelling of the dough corresponds to an increase of volume and not weight.

In addition, children studied the theme of the fermentation of the yeast Saccharomyces cerevisiae as an example of biotechnological process used by man for food production from very ancient times, and in many places of the world. 
The second project was carried out with twenty-seven 10-year-old students at the "Vittorio Alfieri" primary school in Mirano, Italy. It was developed around the theme of the biotechnological application of Streptococcus thermophilus and Lactobacillus bulgaricus bacteria, mainly responsible for the lactic fermentation process in the production of yogurt.

In the first phase of the project, we conducted two laboratory-experimental activities aimed at understanding the biochemical process of lactic fermentation. In addition, by observing the density of the yoghurt, we studied the effect of an acid in the milk. In the second phase, we conducted two other experiments to verify the presence of bacteria inside and outside the body, through Petri capsules that contained microorganisms from farm soil.

\subsection{Lesson Models}

We used two lesson models for the fulfilment of the projects:

The first was the lab. It was a sensory and practical educational format. By using it we lent a coherent structure to the lesson that was organized in three phases:

1) Experimental-observational phase: experiment fulfilment. The realization of the experiments followed the steps of the scientific method.

2) Individual verbalization phase: formulation of individual conceptions. While children were performing the experiments, we suggested that each student should reflect of their lab experience.

3) Collective discussion and final conceptualization phase: peer comparison and restructuring of personal ideas. After students built their own mental representations, there was a moment of collective discussion. This allowed shared ideas to increase knowledge and to elaborate on definitive learning.

The second was the frontal lesson. Some topics needed to be deepened by oral explanations from the teacher, so we decided to alternate frontal lessons with laboratory experiences. However, we tried to make this format of lessons as interactive as possible, avoiding whenever possible one-way communication (from teacher to pupil).

\subsection{Activities}

The fulfilment of activities is summarized in Table 1.

Table 1. Fulfilment of activities

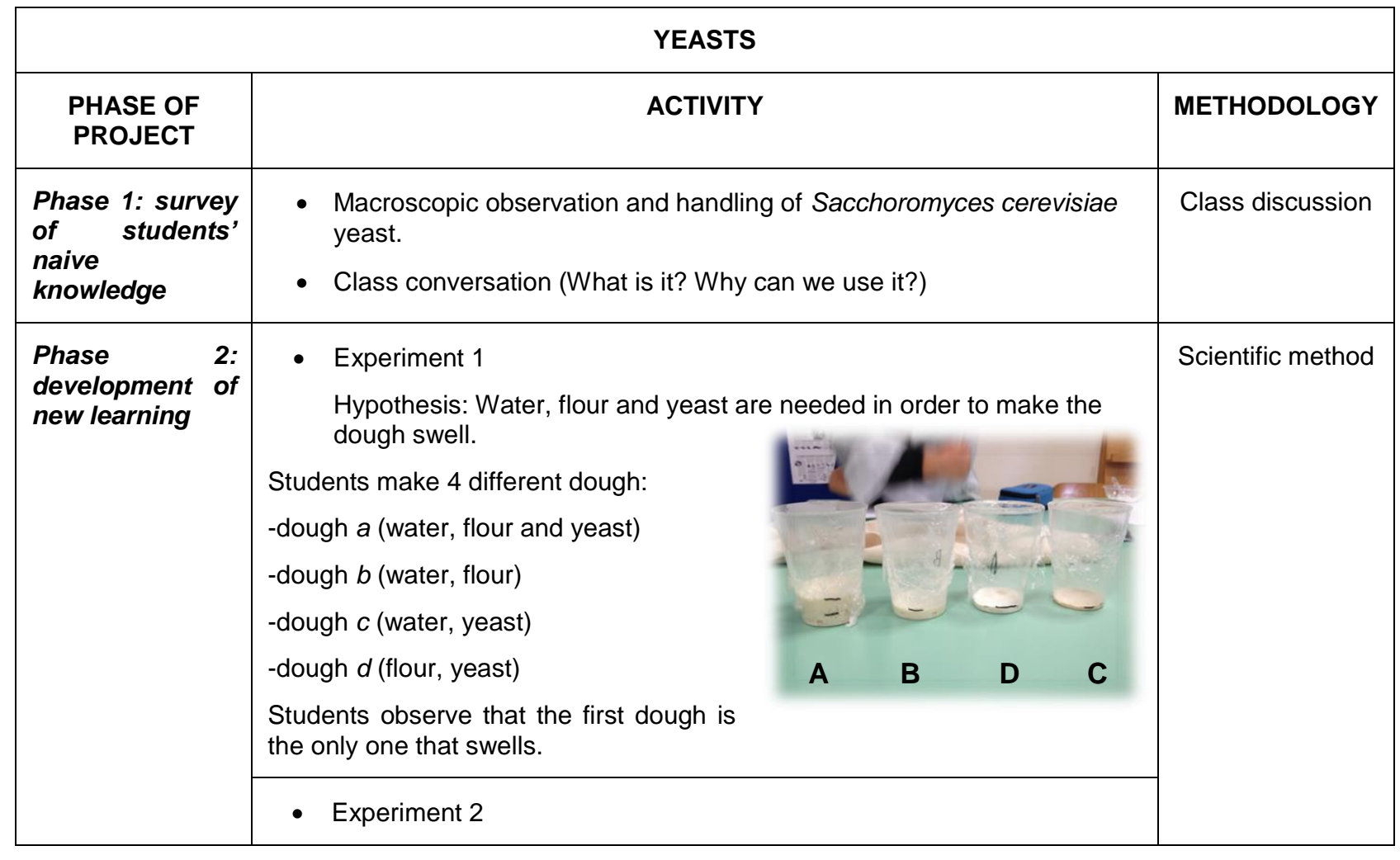




\begin{tabular}{|c|c|c|}
\hline & $\begin{array}{l}\text { Hypothesis: Yeast is the responsible of the swelling of the dough. } \\
\text { Students make } 3 \text { different doughs } \\
\text { and in each one put a different } \\
\text { quantity of yeast. } \\
\text {-dough a ( } 1 \text { spoon of yeast) } \\
\text {-dough b ( } 2 \text { spoons of yeast) } \\
\text {-dough c ( } 3 \text { spoons of yeast) } \\
\text { Students observe that the dough with } \\
\text { a greater quantity of yeast swells } \\
\text { more than the other ones. }\end{array}$ & \\
\hline & $\begin{array}{l}\text { - Observation of the yeast through the } \\
\text { microscope } \\
\text { Students realize that yeast is a unicellular } \\
\text { organism. }\end{array}$ & \\
\hline & $\begin{array}{l}\text { Experiment } 3 \\
\text { Hypothesis 1: the swell of the dough implicates an increase of weight. } \\
\text { Hypothesis 2: the swell of dough does not implicate an increase of weight } \\
\text { because the weight of the ingredients is always the same. } \\
\text { Students make } 2 \text { doughs with different quantities of ingredients. They weigh } \\
\text { each one at the beginning } \\
\text { and after the swelling. } \\
\text { Students realize that the } \\
\text { weight of each dough is } \\
\text { not changed before and } \\
\text { after the swelling. }\end{array}$ & \\
\hline & $\begin{array}{l}\text { - The concept cartoon } \\
\text { The aim of the concept cartoon is to } \\
\text { introduce the alcoholic fermentation. }\end{array}$ & Frontal lesson \\
\hline $\begin{array}{l}\text { Phase 3. The } \\
\text { fermentation as } \\
\text { a } \\
\text { biotechnological } \\
\text { process }\end{array}$ & $\begin{array}{l}\text { Students analyse the fermentation as an example of biotechnological } \\
\text { process. }\end{array}$ & \\
\hline
\end{tabular}


Proceedings of INTCESS 2022- 9th International Conference on Education \& Education of Social Sciences 17-18 January 2022- Online Conference

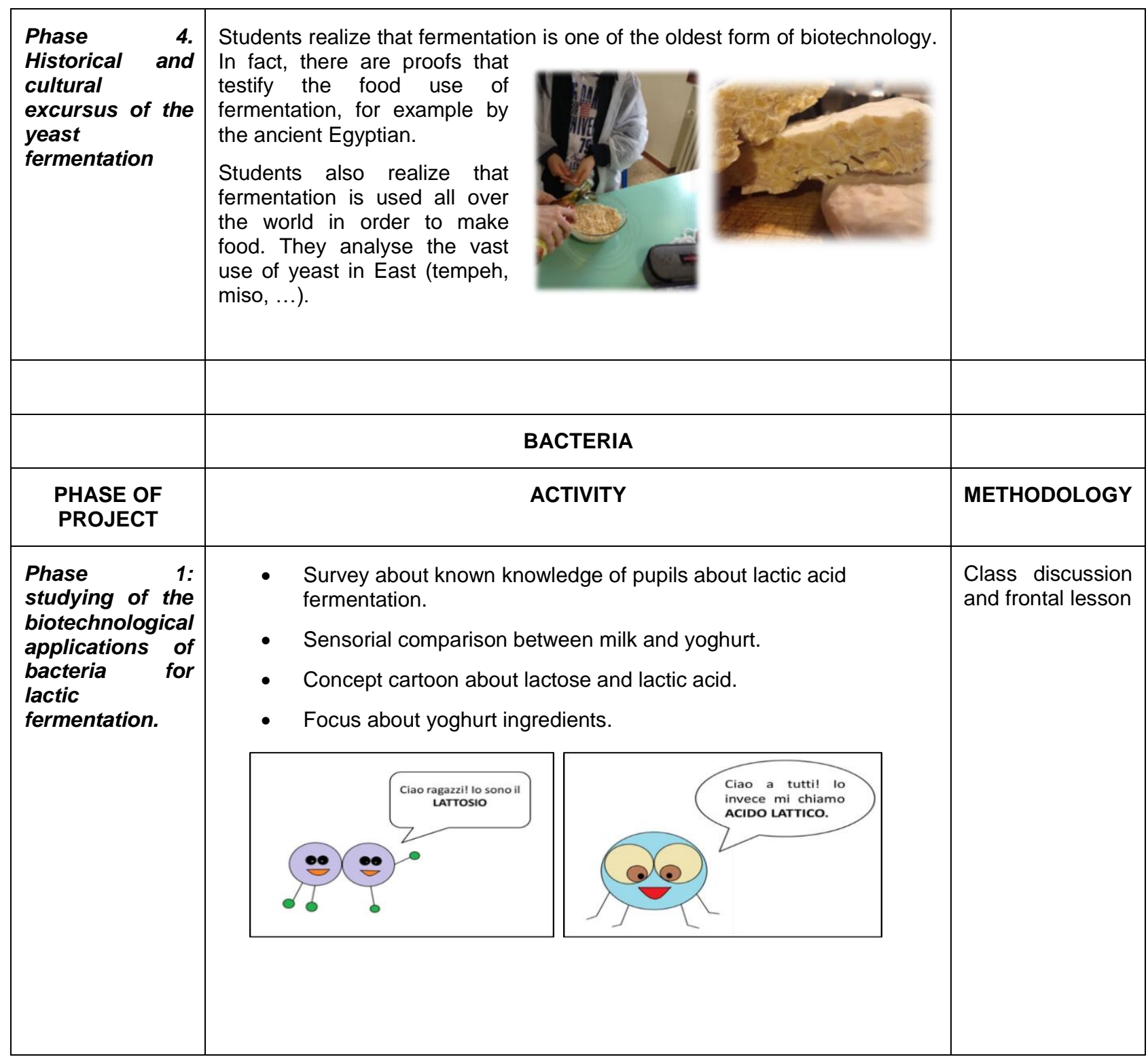


Proceedings of INTCESS 2022- 9th International Conference on Education \& Education of Social Sciences 17-18 January 2022- Online Conference

\begin{tabular}{|c|c|c|c|c|c|}
\hline & 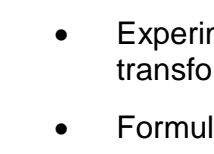 & $\begin{array}{l}\mathrm{t} 1 \text { : Which ingred } \\
\text { tion of milk in yog } \\
n \text { of six hypothes }\end{array}$ & $\begin{array}{l}\text { ents/agents contr } \\
\text { nurt? } \\
\text { s: }\end{array}$ & bute to the & $\begin{array}{l}\text { Laboratory and } \\
\text { scientific method }\end{array}$ \\
\hline & & $\begin{array}{l}\text { WHOLE MILK } \\
\text { AND } \\
\text { LACTOSE }\end{array}$ & $\begin{array}{l}\text { LIGHT MILK } \\
\text { AND } \\
\text { LACTOSE }\end{array}$ & $\begin{array}{l}\text { WHOLE MILK, } \\
\text { WITHOUT } \\
\text { LACTOSE }\end{array}$ & \\
\hline & $\begin{array}{l}\text { +YOGHURT } \\
\text { (with bacteria) }\end{array}$ & Hypothesis 1 & Hypothesis 3 & Hypothesis 5 & \\
\hline & $\begin{array}{l}\text { +BACTERIA } \\
\text { (powder) }\end{array}$ & Hypothesis 2 & Hypothesis 4 & Hypothesis 6 & \\
\hline & $\begin{array}{l}\text { Fulfilm } \\
\text { - } \quad \text { Conclu } \\
\text { fermen } \\
\text { lactose } \\
\text { hypoth }\end{array}$ & $\begin{array}{l}\text { of experiment } 1 \text {. } \\
\text { s: for the lactic } \\
\text { n are necessary } \\
\text { d bacteria (verifie } \\
1,2,3,4) \text {. }\end{array}$ & & & \\
\hline & $\begin{array}{ll}\text { - } & \text { Experir } \\
\text { - } & \text { Fulfillm } \\
\text { - } & \text { Conclu } \\
\text { curding } \\
\text { - } & \text { Formal } \\
\text { knowle } \\
\text { map. }\end{array}$ & $\begin{array}{l}\text { t 2: what is the e } \\
\text { of the experimen } \\
\text { is: acid allows the } \\
\text { the milk. } \\
\text { ion of new } \\
\text { through concept }\end{array}$ & fect of an ac & ilk? & \\
\hline $\begin{array}{l}\text { Phase 2: } \\
\text { Studying of the } \\
\text { presence of } \\
\text { bacteria in the } \\
\text { environment }\end{array}$ & $\begin{array}{ll}\text { - } & \text { Brief di } \\
\text { food bi } \\
\text { - } & \text { Short fr } \\
\text { terrains } \\
\text { - } & \text { Formul } \\
\text { in the } \mathrm{C} \\
\text { - } & \text { Experir } \\
\text { environ }\end{array}$ & $\begin{array}{l}\text { ssions about the } \\
\text { hnology. } \\
\text { al lesson about us } \\
\text { n of different hyp } \\
\text { onment. } \\
\text { t } 3 \text { : Study on the } \\
\text { nt by means of } c 0\end{array}$ & $\begin{array}{l}\text { irth and developr } \\
\text { ing of Petri's cap } \\
\text { thesis about the } \\
\text { resence of bacte } \\
\text { ntamination of cu }\end{array}$ & $\begin{array}{l}\text { nent of yogurt as a } \\
\text { re and cultivation } \\
\text { resence of bacteria } \\
\text { iivation terrains. }\end{array}$ & $\begin{array}{l}\text { Frontal lesson, } \\
\text { laboratory and } \\
\text { scientific method }\end{array}$ \\
\hline
\end{tabular}




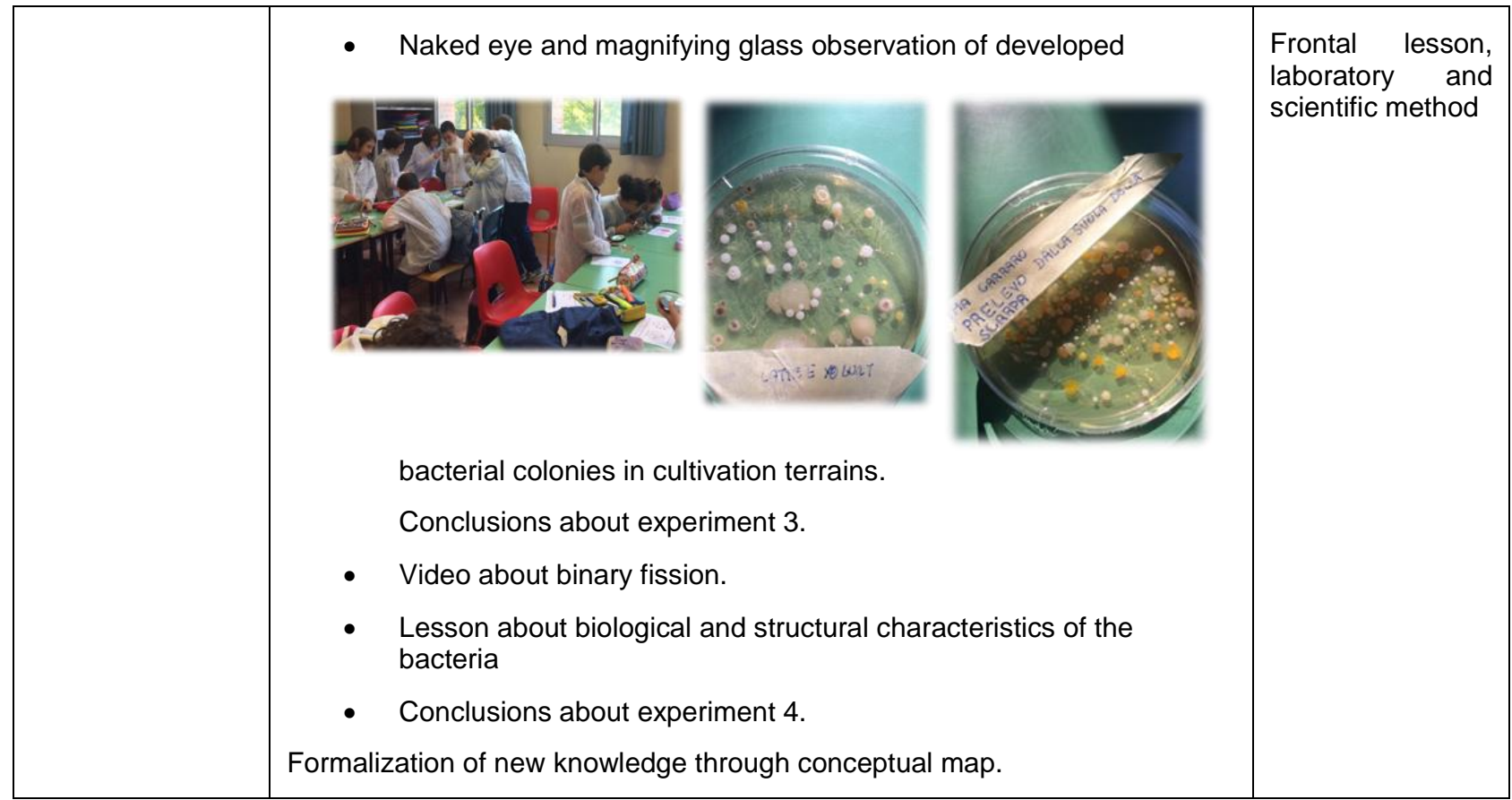

\section{RESULTS AND DISCUSSION}

The last stage of the experimental research consists in a comparison between the "expected data" and the "observed data". The result of this comparison reveals the achievement of both goals of this research. First of all, it proves the current scientific evidence that underlines the effectiveness of didactics laboratory. Secondly, it confirms that this method makes it possible to deal with several topics which are omitted by school programs. In fact, starting from students' interests and making students the main characters can have a great impact on learning because each topic becomes significant.

\subsection{The effectiveness of Didactics Laboratory}

The effectiveness of didactics laboratory is clearly shown in the results that students have achieved during the semi-structured tests.

The Figure 1 describes the level of competence achieved by each student. The test questions were a total of twenty-two and the score of each level of competence has been divided as follows:

- Starting Level, from 0 to 12 correct answers

- Base Level, from 13 to 15 correct answers

- Medium Level, from 16 to 18 correct answers

- Advanced Level, from 19 to 22 correct answers

Looking at the Figure 1, it is clear that most of the students achieved the Advanced Level. This data is very interesting. It demonstrates the effectiveness of didactic laboratory and that laboratory activities, conducted through experimental methods, have a strong impact on learning.

The students can gradually formalize their knowledge using their problem-solving skills. Didactic laboratory has a positive impact also with student who have some learning difficulties (Base Level). In fact, it allows creating an inclusive experience in which everyone can take part because everyone can be aware of what he can do. 


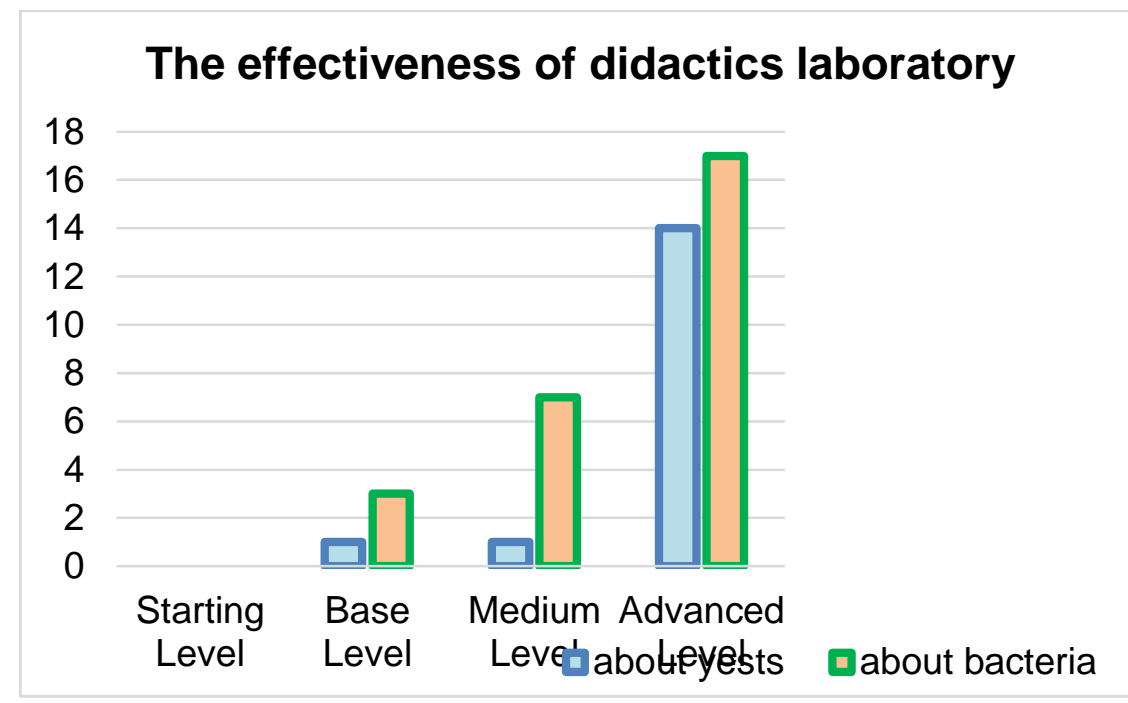

Figure 1. The effectiveness of didactics

\subsection{The impact of Didactic Laboratories on Supporting the Motivation to Learn}

The impact of didactic laboratories on supporting the motivation to learn is proved by the high appreciation that student have shown. Self-assessment requires students to reflect on their own work and to judge how well they have performed in order to identify their strengths, weaknesses, and areas that require improvement.

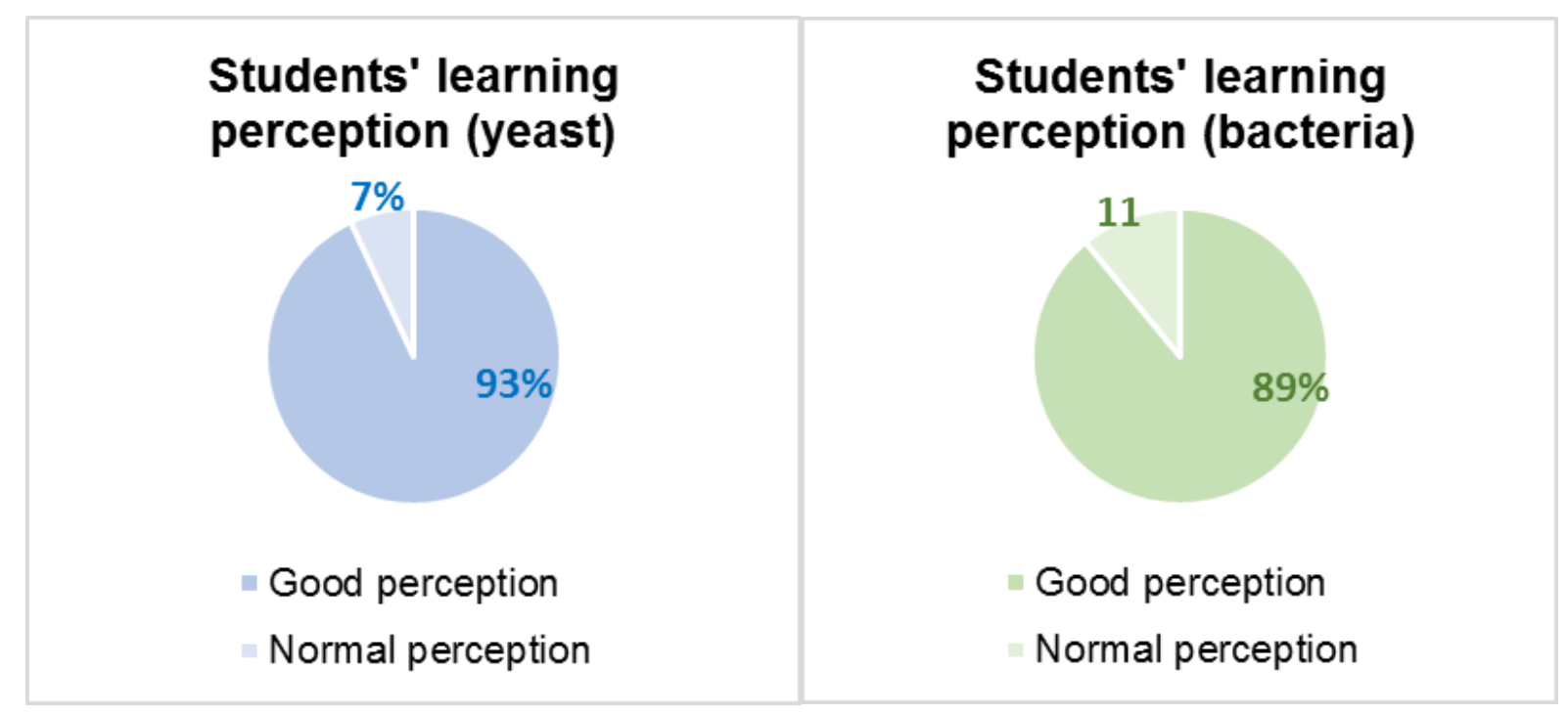

Figure 2. Students' learning perception

The graphic in Figure 2 describes the students' learning perception. Most of them have a good perception about their success. They thought they achieved a good competence level, and this data is confirmed by the tests' results.

\section{CONCLUSIONS}

Observing the results of our educational paths, it appears that didactic laboratories and experimental methods are efficient for encouraging the learning processes. This method could really make a difference because it allows actual real-life observation, asking personal questions and formulating hypothesis and, finally, finding answers. There is nothing better than "touching with hands" phenomena that surround us. This method also facilitates the inclusion of all pupils, in particular of the ones with special educational needs. All children, without exception, contributed to the co-construction of new knowledge, motivated by the research of answers coming from themselves.

Secondly, the results prove that this method makes it possible to deal with several topics which are not 
currently mentioned in the Italian Guidelines for primary school.

About the method, to find out some answers it would be necessary to go forward to a "didactic of doing," which consists in making real experiences of the theme debated (Santovito, 2015). This also means carrying out active teaching methods and offering learning opportunities through the laboratory. These methods require a great dedication for the organization of the experiences but promise a long and consolidated learning in a lifelong perspective. We also believe that it is essential to start from everyday life of pupils, from the phenomena of which they experience every day and, probably, take for granted. For example, for observing the results of biotechnological application of microorganisms such as yeasts and bacteria, it is just necessary to observe basic foods such as yoghurt, bread, cakes, wine, vinegar and many other ingredients easily found in the kitchen. The interest for the microscopic world should arise from its strangeness. Even though it is unseen, it affects considerably the existence of people, from many points of view. So, didactic proposals of this kind certainly should raise interest in pupils. Furthermore, they should promote the increase of scientific culture in children, who are the future citizens of tomorrow, with significant social-economic implications for our society.

\section{REFERENCE LIST}

Alfieri, F., Arcà, M. \& Guidoni, P. (1995) Il senso di fare scienze. Un esempio di mediazione tra cultura e scuola. Bollati Boringhieri, Torino.

Barana, C., Dall'Acqua d'Industria, L., Bellio, M., Corrà, F., Bonato, M., Schumann, S., Irato, P. \& Santovito, G. (2021) "Teacher, may we touch it?" An innovative laboratory approach to address macroscopic and microscopic anatomy of the digestive system of human and mammals in primary school. In: INTED2021 Proceedings, IATED, Valencia, https://doi.org/10.21125/inted.2021.0210

Barbacovi, V., Santovito, G. \& Irato, P. (2018) Little scientists for large discoveries: an experimental approach to survey the world with classes ii of the primary school - The observation and study of plant life. In: EDULEARN18 Proceedings, IATED, Valencia. https://doi.org/10.21125/edulearn.2018.1579

Bassi, C., Fattori, G., Bellio, M., Corrà, F., Bonato, M., Schumann, S., Irato, P. \& Santovito, G. (2021) Feel with the skin. A didactic research to introduce the integumentary system and sensory perception in primary school. In: EDULEARN21 Proceedings, IATED, Valencia. https://doi.org/10.21125/edulearn.2021.1352

Bertoncello, O., De Rosso, A. \& Santovito, G. (2021) My classroom as big as the world of CAITPR. An innovative educational-didactic approach for the training of eco-sensitive citizens. In: EDULEARN21 Proceedings, IATED, Valencia. https://doi.org/10.21125/edulearn.2021.0372

Bortolami, I., Bisaccia, P., Corrà, F., Bonato, M., Irato, P. \& Santovito, G. (2020) The blue gold: an empirical research to introduce the discussion of water issue in relation to plants, animals and human in primary school. In: EDULEARN20 Proceedings, IATED, Valencia, https://doi.org/10.21125/edulearn.2020.0496.

Calvani, A. (2011) Principi dell'istruzione e strategie per insegnare: Criteri per una didattica efficace. Carrocci, Roma.

Capparotto, A., Bramuzzo, S., Callegaro, E., Poloni, E., Corrà, F. \& Santovito G. (2017) The didactics of biology in primary school: an innovative approach to skeletal system teaching in fifth class based on comparative vertebrate anatomy. In: INTED2017 Proceedings, IATED, Valencia. http://doi.org/10.21125/inted.2017.0935

Castoldi, M. (2011) Progettare per competenze: Percorsi e strumenti. Carocci, Roma.

Chiesa, E., Irato, P. \& Santovito, G. (2019) The circulatory system of vertebrates and invertebrates: an empirical research to introduce in the fourth class the treatment of animal morphology in a comparative key. In: INTED2019 Proceedings, IATED, Valencia. https://doi.org/10.21125/inted.2019.0391

Corbolino, N., Bisaccia, P., Corrà, F., Bonato, M., Irato, P. \& Santovito, G. (2020) The vegetable garden. an instrument for sustainable development education and care pedagogy. In: INTED2020 Proceedings, IATED, Valencia, https://doi.org/10.21125/inted.2020.1282. 
Fabris, G., Bisaccia, P., Corrà, F., Bonato, M., Irato, P. \& Santovito, G. (2020) Discovering the nervous system. An innovative teaching approach for primary school. In: EDULEARN20 Proceedings, IATED, Valencia, https://doi.org/10.21125/edulearn.2020.0889.

Fassinato, C., Nicorelli, E., Corrà, F., Irato, P., Guidolin, L. \& Santovito G. (2018) An innovative approach to deal with biodiversity at school with its investigation in different environments. In: EDULEARN18 Proceedings, IATED, Valencia. https://doi.org/10.21125/edulearn.2018.0717

Favaron, A., Ancona, E., Bramuzzo, S., Callegaro, E., Guidolin, L., Irato, P. \& Santovito, G. (2017) An innovative teaching approach to circulatory and skeletal systems based on comparative vertebrate anatomy and physiology. In: EDULEARN17 Proceedings, IATED, Valencia. http://doi.org/10.21125/edulearn.2017.1015

Forlin, E., Santovito, G., Guidolin, L. \& Irato, P. (2018) Citrus fruits. Course to educate to scientific curiosity. In: EDULEARN18 Proceedings, IATED, Valencia. https://doi.org/10.21125/edulearn.2018.1573

Frigerio, R., Bellio, M., Bonato, M., Santovito, G. \& Irato, P. (2021) Fruit and vegetables: discovering conscious food choices. Creation of an educational project to stimulate the study of science in a class ii of a lower secondary school. In: EDULEARN21 Proceedings, IATED, Valencia. https://doi.org/10.21125/edulearn.2021.1329

Furlan S., Bellio M., Corrà F., Bonato M., Schumann S., Irato P., Tamino G., Santovito G. (2021) A, B, C, D... NA: Genetics explained to children. an innovative didactic and laboratory proposal in primary school. In: EDULEARN21 Proceedings, IATED, Valencia. https://doi.org/10.21125/edulearn.2021.1216

Furlanetto, L., Bellio, M., Corrà, F., Bonato, M., Schumann, S., Irato, P. \& Santovito G. (2021) The circle of life. Human reproduction and embryonic development in primary school. In: INTED2021 Proceedings, IATED, Valencia, https://doi.org/10.21125/inted.2021.0209

Gainotti, A. \& Modelli, A. (2008) Scienze della natura. Zanichelli, Bologna.

Gaiotto, A., Tonon, S. \& Santovito, G. (2013) The scientific method in the teaching of life sciences in primary school, The plants and their seasonal changes". In EDULEARN13 Proceedings, pp. 4226-4235.

Gaiotto, A. \& Santovito G. (2016) An innovative didactic approach to the study of invertebrate animals in primary school. In: EDULEARN16 Proceedings, IATED, Valencia. http://doi.org/10.21125/edulearn.2016.1284

Gaiotto, A., Bisaccia, P., Bonato, M., Irato, P., Corrà, F. \& Santovito, G. (2020) The plants and their seasonal changes: teaching biology in primary school using the scientific method. In: INTCESS2020 Proceedings, OCERINT, Istanbul, pp 261-270.

Gallina, S., Irato, P. \& Santovito, G. (2019) Inquiry into animal tracks: an experimental application of IBSE inquiry based science education- approach in the ecological field in primary school. In: INTED2019 Proceedings, IATED, Valencia. https://doi.org/10.21125/inted.2019.0089

Grando, G., Bramuzzo, S., Irato, P., Guidolin, L., Ferrari, L. \& Santovito, G. (2018) Introduction to the world of insects: a didactic research in kindergarten. In: INTED2018 Proceedings, IATED, Valencia. https://doi.org/10.21125/inted.2018.1066

Grando, G, Bramuzzo, S., Callegaro, E., Guidolin, L., Irato, P. \& Santovito, G. (2018) Who is afraid of insects? A didactic research in the biological field in kindergarten. In: EDULEARN18 Proceedings, IATED, Valencia. https://doi.org/10.21125/edulearn.2018.0724

Lago, A., Masiero, S., Bramuzzo, S., Callegaro, E., Poloni, E., Corrà, F. \& Santovito G. (2017) Exploring microbiology and biotechnologies: a laboratory approach to the study of yeasts and bacteria in primary school. In: INTED2017 Proceedings, IATED, Valencia. http://doi.org/10.21125/inted.2017.0992

Longo, C. (1998). Didattica della biologia. La Nuova Italia Editrice, Firenze.

Lui, F., Irato, P. \& Santovito, G. (2019) Discovering living organisms: a didactic research to introduce biology in kindergarten. In: EDULEARN19 Proceedings, IATED, Valencia. https://doi.org/10.21125/edulearn.2019.1040

Meneghetti, G, Bramuzzo, S., Callegaro, E., Guidolin, L., Irato, P. \& Santovito G. (2017) The kingdom of fungi in primary school: an educational research in biology field. In: EDULEARN17 Proceedings, 
IATED, Valencia. https://doi.org/10.21125/edulearn.2017.1023

Palmieri, G., Irato, P., Nicolosi, P. \& Santovito, G. (2019) A day at the museum. Laboratory teaching in the Museum of Zoology at the University of Padua for primary school. In: EDULEARN19 Proceedings, IATED, Valencia. https://doi.org/10.21125/edulearn.2019.1037

Pavan, C. \& Santovito, G. (2014) The laboratory didactics in the teaching -learning processes of life sciences. an educational project on microorganisms in the alimentation in primary school. In: EDULEARN14 Proceedings, IATED, Valencia, pp 7546-7555.

Pavan, C., Bellio, M., Corrà, F., Bonato, M., Schumann, S., Irato, P. \& Santovito, G. (2021) Microorganisms in the alimentation in primary school: the laboratory didactics in the teaching - learning processes of life sciences. In: INTCESS2021 Proceedings, OCERINT, Istanbul. https://doi.org/10.51508/intcess.202176

Rossi, E. \& Santovito, G. (2016) Introduction to Mendelian genetics in primary school. In EDULEARN16 Proceedings, IATED, Valencia. http://doi.org/10.21125/edulearn.2016.1274

Santovito, G. (2015) Insegnare la biologia ai bambini. Dalla scuola dell'infanzia al primo ciclo d'istruzione. Carocci, Roma.

Toninato, V. \& Santovito, G. (2015) The laboratory didactics in the teaching-learning processes of life sciences. an educational project on the structure of the flower and the inflorescences phenomenon in primary school. In: EDULEARN15 Proceedings, IATED, Valencia, pp 2245-2254.

Tonon, S., Gaiotto, A. \& Santovito, G. (2013) The active teaching of life sciences in primary school: a comparative approach to the musculoskeletal system. In: EDULEARN13 Proceedings, IATED, Valencia, pp. 4289-4298.

Tonon, S., Bisaccia, P., Bonato, M., Irato, P., Corrà, F. \& Santovito, G. (2020) A comparative approach to the musculoskeletal system in primary school. In: INTCESS2020 Proceedings, OCERINT, Istanbul, pp 251-260.

Trevisan, T. \& Santovito, G. (2015) Teaching evolution: a laboratory approach. In: EDULEARN15 Proceedings, IATED, Valencia, pp 2234-2244.

Tura, N., Guidolin, L., Irato, P. \& Santovito, G. (2018) From cell to inheritance of characters: an introduction to classical genetics in primary school. In: INTED2018 Proceedings, IATED, Valencia. https://doi.org/10.21125/inted.2018.1076

Zanata, M. \& Santovito, G. (2020) The "Da Vinci" Biodiversity Park (Treviso, Italy). A didactic garden as innovative support to the teaching of science in secondary school. In: INTED2020 Proceedings, IATED, Valencia, https://doi.org/10.21125/inted.2020.1474.

Zandonella Necca, I., Bellio, M., Corrà, F., Bonato, M., Schumann, S., Irato, P., Tamino, G. \& Santovito, G. (2021) Sustainable food: an innovative approach based on the assessment for learning method in secondary schools. In: INTCESS2021 Proceedings, OCERINT, Istanbul, https://doi.org/10.51508/intcess.202177

Zandonella Necca, I., Tamino, G. \& Santovito, G. (2014) Sustainable food: an educational proposal, for key stage 3 in secondary schools, based on the assessment for learning method. In: EDULEARN14 Proceedings, IATED, Valencia, pp 7348-7356. 